\title{
Visual Evaluation of In Vitro Cariostatic Effect of Restorative Materials Associated With Dentifrices
}

\author{
José Augusto RODRIGUES ${ }^{1}$ \\ Giselle Maria MARCHI ${ }^{1}$ \\ Mônica Campos SERRA ${ }^{2}$ \\ Anderson Takeo HARA ${ }^{1}$ \\ ${ }^{1}$ Department of Restorative Dentistry, Faculty of Dentistry of Piracicaba, \\ State University of Campinas (UNICAMP), Piracicaba, SP, Brazil \\ ${ }^{2}$ Department of Restorative Dentistry, Faculty of Dentistry of Ribeirão Preto, \\ University of São Paulo, Ribeirão Preto, SP, Brazil
}

\begin{abstract}
This study evaluated in vitro the cariostatic effect of 6 restorative materials with and without fluoride release (Fuji II LC, F-2000, Degufil Mineral, Sure Fil and Z-250) associated with a fluoridated and a non-fluoridated dentifrice (Sensodyne Original Formula and Sensodyne Sodium Bicarbonate), on human enamel. Class V-like cavities were prepared on 240 enamel slabs, assigned to 12 groups (6 materials and 2 dentifrices). After cavity restoration, the slabs were submitted to a thermocycling regimen of 1000 thermal cycles and demineralization/remineralization cycles. During $\mathrm{pH}$ cycles, slurries of fluoridated and non-fluoridated dentifrices were applied for 5 min. Formation of artificial caries-like lesions was scored independently and blindly by 5 calibrated examiners according to an ordinal scale ranked 0 to 3 by visual examination. The results were analyzed statistically by the Kruskal-Wallis test and pair-wise comparisons $(\alpha=0.05)$. There were no significant differences ( $>>0.05)$ among the restorative materials associated with the fluoridated dentifrice. When used in association with the non-fluoridated dentifrice, Ketac-Fil showed the highest cariostatic effect followed by Fuji II LC and the other materials. Ketac-Fil was the only material that did not differ statistically when combined with either the fluoridated or the non-fluoridated dentifrice. In conclusion, under the tested experimental conditions, the association of restorative materials and fluoridated dentifrice yielded higher cariostatic effect, except for the conventional glass ionomer cement, whose cariostatic effect was not influenced by the type of dentifrice.
\end{abstract}

Key Words: enamel, dental caries, diagnosis, glass ionomer cement, composite resin.

\section{INTRODUCTION}

Dental caries is caused by acidic action produced by bacteria from dental biofilm and a change in the equilibrium between demineralization and remineralization, which favors demineralization (1). Replacement of restorations due to secondary caries is a continuing problem in restorative dentistry $(1,2)$. Topical fluoride is a commonly used method to prevent and/or arrest dental caries, which decreases the $\mathrm{pH}$ of tooth dissolution, inhibiting demineralization and enhancing the remineralization process (3).

The use of fluoride-releasing restorative materials for cariostatic purposes has received increasing emphasis (4-7). Reports have shown that fluoride release on the restoration margins can inhibit secondary caries development $(7,8)$. Previous studies have shown that fluoride-releasing conventional glass-ionomer cements have high cariostatic effect $(7,9)$, fluoridated composites have a low cariostatic effect $(7,8)$ and glass-ionomer/ composite resin hybrid materials have an intermediate cariostatic effect $(2,7,9)$ or an effect similar to that of the conventional glass ionomer cement $(4,6,10,11)$.

Although fluoride-releasing restorative materials are able to interfere with the progression of caries lesions around restorations at different levels, they still cannot prevent caries development $(5,7)$. As a strategy, the use of fluoride dentifrices has been recommended to obtain additional fluoride supply in the oral cavity (5). It is reasonable to assume that if patients who have fluoride-releasing restorations use a fluoridated dentifrice regularly, there may be an increase in the fluoride level in the oral cavity (5). However, the cariostatic potential produced with the combination of fluoride-releasing

Correspondece: Profa. Dra. Giselle Maria Marchi, Departamento de Odontologia Restauradora, Faculdade de Odontologia de Piracicaba (UNICAMP), Avenida Limeira, 901, Areião, 13141-900 Piracicaba, SP, Brasil. Tel: +55-19-3412-5337. Fax: +55-19-3412-5218. e-mail: gimarchi@fop.unicamp.br 
restorative materials and topical fluorides is unknown. The purpose of this study was to evaluate the cariostatic effect of 6 restorative materials with and without fluoride release used in association with a fluoridated and a non-fluoridated dentifrice, on human enamel.

\section{MATERIAL AND METHODS}

The research proposal was first submitted to the Ethics Research Committee at the Faculty of Dentistry of Piracicaba (UNICAMP) and the designed methodology was approved, in agreement with the CNS 196/96 resolution from the Brazilian National
Council of Health/Health Department.

Six restorative systems (Table 1 ) and 2 dentifrices (a fluoridated and a non-fluoridated) (Table 2) were evaluated in this study. The factorial design to test the effects of the materials and dentifrices resulted in 12 experimental groups. A total of 240 dental slabs $(n=20 /$ group) were restored in 10 blocks. In each stage, 2 restorations of each restorative system were made according to a randomized complete block design with 2 replications per block. The qualitative response variable, formation of artificial caries-like lesion, was evaluated blindly and independently by 5 calibrated examiners using an ordinal scale based on visual examination.

Table 1. Restorative systems, presence/absence of fluoride and manufacturers’ informations.

\begin{tabular}{|c|c|c|c|}
\hline Brand name & Batch & Type of material & Manufacturer \\
\hline Ketac-Fil (yes) & $\begin{array}{l}\text { FW } 0055787 \\
\text { W0055375 }\end{array}$ & $\begin{array}{l}\text { Conventional glass } \\
\text { ionomer cement }\end{array}$ & Ketac-Fil, ESPE, Seefeld, Germany \\
\hline Fuji II LC (yes) & $\begin{array}{l}070591 \\
230491\end{array}$ & Resin-modified glass ionomer & GC Corporation, Tokyo, Japan \\
\hline $\begin{array}{l}\text { F2000 (yes) } \\
\text { Single Bond (no) }\end{array}$ & $\begin{array}{l}7 \mathrm{~N} \\
9 \mathrm{DV}\end{array}$ & $\begin{array}{l}\text { Polyacid-modified composite resin and } \\
\text { single-bottle adhesive system }\end{array}$ & 3M/ESPE, St. Paul, MN, USA \\
\hline $\begin{array}{l}\text { Degufil Mineral (yes) } \\
\text { Etch \& Prime } 3.0 \text { (no) }\end{array}$ & $\begin{array}{c}309 \\
029913 \\
039923\end{array}$ & $\begin{array}{l}\text { Fluoridated composite resin } \\
\text { and self-etching adhesive system }\end{array}$ & Degussa-Hülls AG, Hanau, Germany \\
\hline $\begin{array}{l}\text { Surefil (A) (no) } \\
\text { Prime \& Bond NT (yes) }\end{array}$ & $\begin{array}{c}990216 \\
9811001112\end{array}$ & $\begin{array}{c}\text { Composite resin and adhesive system } \\
\text { with fluoride }\end{array}$ & $\begin{array}{l}\text { Dentsply Caulk, } \\
\text { Milford, DE, USA }\end{array}$ \\
\hline $\begin{array}{l}\text { Z } 250 \text { (A3) (no) } \\
\text { Single Bond (no) }\end{array}$ & $\begin{array}{l}9 \mathrm{CP} \\
9 \mathrm{DV}\end{array}$ & $\begin{array}{l}\text { Composite resin and single-bottle } \\
\text { adhesive system }\end{array}$ & 3M/ESPE, St. Paul, MN, USA \\
\hline
\end{tabular}

(yes): presence of fluoride; (no): absence of fluoride.

Table 2 - Dentifrices used and fluoride concentration contents.

\begin{tabular}{lccc}
\hline Dentifrice & Batch & Fluoride content* & Manufacturer \\
\hline Sensodyne Original Formula & 003005 & $7.0 \mathrm{ppm}$ & Stafford Miller Ind. Ltd. \\
& 003004 & & Rio de Janeiro, RJ, Brazil \\
& 909001 & & \\
Sensodyne Sodium Bicarbonate & 912027 & $1411.6 \mathrm{ppm}$ & Stafford Miller Ind. Ltd. \\
& 002038 & & Rio de Janeiro, RJ, Brazil
\end{tabular}

*Fluoride concentration was evaluated at the Biochemistry Laboratory of the Faculty of Dentistry of Piracicaba (UNICAMP), Piracicaba, Brazil. 
For specimen preparation, unerupted third molars were selected and stored in a $10 \%$ formalin solution $(\mathrm{pH}$ 7). The teeth were submitted to a soft-tissue debridement with periodontal curettes and cleaned with water/pumice slurry in webbed rubber cups in a low-speed handpiece (Kavo do Brasil, Joinville, SC, Brazil). The roots were removed, the crowns were sectioned longitudinally and transversally to obtain 240 dental enamel/dentin slabs (4 mm x 4 mm x $3 \mathrm{~mm}$ ) using double-faced diamond discs (KG Sorensen, Barueri, SP, Brazil). Cylindrical class Vlike cavities (1.8 mm in diameter and $1.8 \mathrm{~mm}$ deep) were prepared in the center of the slabs with a \#2094 diamond bur (KG Sorensen, Barueri, SP, Brazil) in a high-speed handpiece (Kavo do Brasil) with constant water spray coolant. The handpiece was attached to a cavity preparation machine to provide standard cavity dimensions.

The slabs were randomly assigned to 12 groups $(n=20)$. Each group of slabs was restored with one of the six restorative materials associated to one of the two dentifrices. Restorations were done in 10 blocks, in which two slabs per group were filled. The sequence of restoration was determined at random and the materials were inserted according to the manufacturers' instructions.

Ketac-Fil. Ketac conditioner was applied for $10 \mathrm{~s}$, rinsed and dried for $10 \mathrm{~s}$. Ketac-Fil was prepared at a 3.2 $\mathrm{g} / 1.0 \mathrm{~g}$ ratio, the powder being divided into 2 equal portions. The first portion was mixed with all the liquid for 10-15 $\mathrm{s}$ and the remaining powder was incorporated within 20-25 s. The material was inserted with a centrix injector, protected with a lead strip for $5 \mathrm{~min}$, coated with Ketac-Glaze and light-cured for $20 \mathrm{~s}$.

Fuji II LC. GC Conditioner was applied for $10 \mathrm{~s}$, rinsed with water and dried. Fuji II LC was prepared at a $3.2 \mathrm{~g} / 1.0 \mathrm{~g}$ ratio, the powder being divided into 2 equal portions. The first portion was mixed with all the liquid for 10-15 s and the remaining powder was incorporated within 20-25 s. The material was inserted with a syringe and light cured for $20 \mathrm{~s}$. A coat of GC Fuji Varnish was applied.

F-200. 3M Scotch Bond etchant was applied for $15 \mathrm{~s}$, washed for $10 \mathrm{~s}$ and dried. Two coats of 3M Single Bond were applied, dried for $5 \mathrm{~s}$ and light-cured for 10 s. The material was inserted and polymerized for $40 \mathrm{~s}$.

Degufil Mineral. One drop of Universal and one drop of Catalyst of Etch \& Prime 3.0 self-etching primer, were mixed thoroughly on a mixing block with a brush tip. A generous amount of the material was applied using a saturated brush tip and allowed to act for $30 \mathrm{~s}$. Excess solvent was air-thinned for $5 \mathrm{~s}$, and the material was light-cured for $10 \mathrm{~s}$. The composite resin was inserted and light cured for $40 \mathrm{~s}$.

Sure Fil. Caulk 34\% Tooth Conditioner gel was applied for $15 \mathrm{~s}$, rinsed for $10 \mathrm{~s}$ and dried. Prime and Bond NT was applied for $20 \mathrm{~s}$, gently air-dried for $5 \mathrm{~s}$ and light cured for $10 \mathrm{~s}$. Sure Fil was inserted and lightcured for $40 \mathrm{~s}$.

Z-250. 3M Scotch Bond etchant was applied for $15 \mathrm{~s}$, rinsed for $10 \mathrm{~s}$ and air-dried. Two coats of $3 \mathrm{M}$ Single Bond were applied, air-dried for $5 \mathrm{~s}$ and lightcured for $10 \mathrm{~s}$. The composite resin was inserted and light-cured for $20 \mathrm{~s}$.

The cavities were restored in a single increment at $\pm 25^{\circ} \mathrm{C}$. Degulux Soft-Start light-curing unit was used (Degussa Hüls AG, Hanau, Germany), with approximately $800 \mathrm{~mW} / \mathrm{cm}^{2}$.

The restored slabs were stored in deionized distilled water for $24 \mathrm{~h}$, after which the restorations were finished with a graded series aluminum-oxide discs (Sof-Lex; 3M do Brasil, Sumaré, SP, Brazil). The restorations were polished under water-cooling at a low speed. Ketac-Fil and Fuji II LC restorations were polished until all varnish was removed.

The slabs were individually immersed in $1 \mathrm{~mL}$ of deionized distilled water to avoid ionic changes and thermocycled together in a thermocycling machine (MCT2; Instrumental Instrumentos de Precisão Ltda, São Paulo, SP, Brazil), for 1000 cycles in water between $5 \pm 2^{\circ} \mathrm{C}$ and $55 \pm 2^{\circ} \mathrm{C}$ with a dwell time of $2 \mathrm{~min}$ for each bath and a 15-s transfer time between baths.

A uniform area of exposed enamel surrounding the restorations was obtained by covering the remaining of the dental slab with red wax. To simulate in vivo high caries risk conditions, a demineralization/remineralization dynamic model, as proposed by Featherstone et al. (12), was used and modified to allow dentifrice application during caries challenge. This model simultaneously measures the net result of the inhibition of demineralization and the enhancement of remineralization. The demineralization stage uses an acid buffer containing $2 \mathrm{mmol} / \mathrm{L} \mathrm{Ca}, 2 \mathrm{mmol} / \mathrm{L} \mathrm{PO}_{4}$, $0.075 \mathrm{~mol} / \mathrm{L}$ acetate at $\mathrm{pH} 4.3$. The remineralization solution contains calcium and phosphate at a know degree of saturation, to mimic the remineralizing properties of saliva, and $50 \mathrm{mmol} / \mathrm{L} \mathrm{KCl}, 1.5 \mathrm{mmol} / \mathrm{L}$ 
Ca $0.9 \mathrm{mmol} / \mathrm{L} \mathrm{PO}_{4}, 20 \mathrm{mmol} / \mathrm{L}$ tri-hydroxymethylaminomathan buffer at $\mathrm{pH} 7.0(7,13)$.

The slabs were immersed separately in $15 \mathrm{~mL}$ of demineralization solution for $6 \mathrm{~h}$, washed with deionized distilled water, immersed in $5 \mathrm{~mL}$ of dentifrice slurry (Table 2) for $5 \mathrm{~min}$, washed with deionized distilled water, immersed in $15 \mathrm{~mL}$ of remineralization solution for $18 \mathrm{~h}$, washed and immersed in demineralization solution, thereby initiating a new cycle. The $\mathrm{pH}$ cycles were conducted during 14 days with 10 daily cycles. In the 6th, 7th, 13th and 14th days of the cycle, the slabs were kept only in the remineralization solution $(7,13)$.

At the end of the $\mathrm{pH}$ cycles, the wax was eliminated, the slabs were air-dried for $15 \mathrm{~s}$ and 5 calibrated graduate students evaluated independently and blindly all slabs. Calibration was performed with 20 slabs selected at random among the groups. The examiners evaluated these specimens scoring the presence and severity of caries-like lesions according to an ordinal scale ranked 0 to 3 based by visual examination, as described by Serra (13) and Serra and Rodrigues Jr. (7) (Fig. 1).

An average score was obtained from scores given by the five examiners for each experimental unit. Differences among the medians were analyzed by

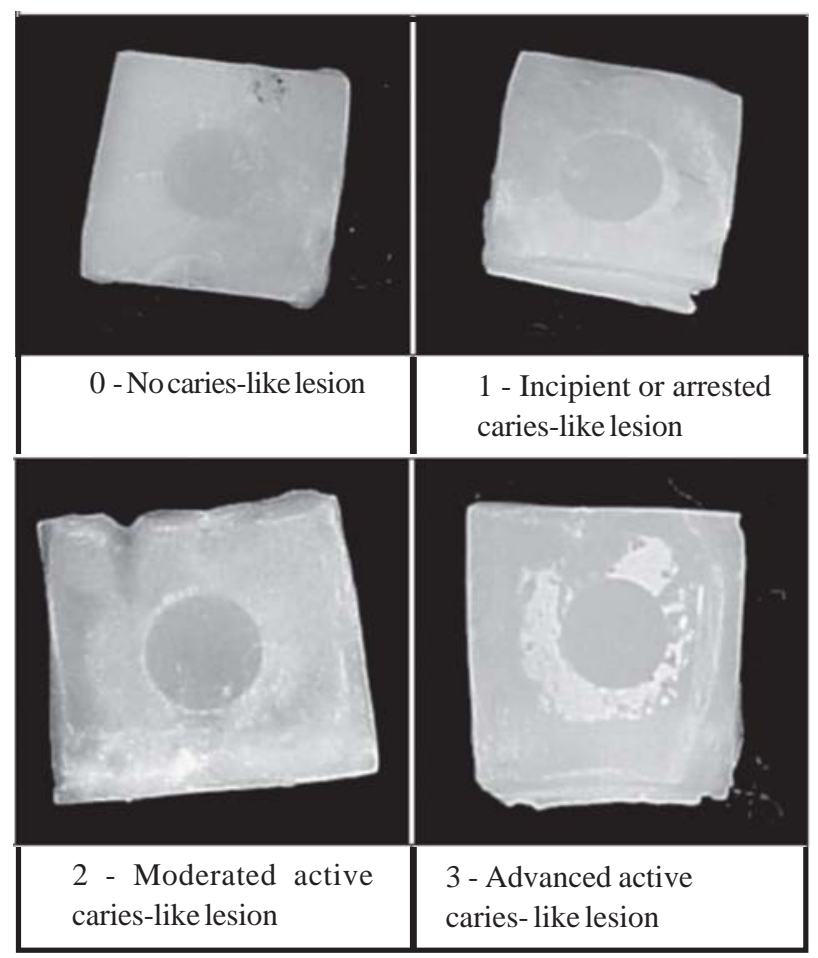

Figure 1. Representative slabs of the scores from the ordinal scale used for visual examination.
Kruskal-Wallis non-parametric test at a 95\% confidence level. Least significant differences (lsd), were used for pair-wise comparisons of the average ranks to check differences among the groups. Statgraphic Plus software (Manugistics, Rockville, Maryland, USA) was used for statistical analysis.

\section{RESULTS}

The Kruskal-Wallis test showed statistically significant differences among the groups ( $h=76.99$; $\mathrm{p}<0.05$ ). Least significant differences were calculated to make the multiple comparisons among the average ranks. The results of these comparisons as well as the values of the effect (median) and the variation (amplitude) are shown in Figure 2 and Table 3.

Combined with the non-fluoridated dentifrice, the conventional glass ionomer cement (Ketac-fil) had the highest cariostatic effect but did not differ statistically from the resin modified glass ionomer cement (Fuji II LC). Fuji II LC, in turn, did not differ from the other materials (F-2000, Degufil Mineral, Sure Fil and Z-250), which had similar results among each other and differed statistically from Ketac-Fil.

When used in association with the fluoridated dentifrice, the materials had statistically similar results among each other. For all restorative systems, the association of a fluoridated dentifrice yielded a statistically higher cariostatic effect. However, the conventional glass ionomer cement was the only material that showed the same statistically cariostatic effect when associated with either a fluoridated or a non-fluoridated dentifrice.

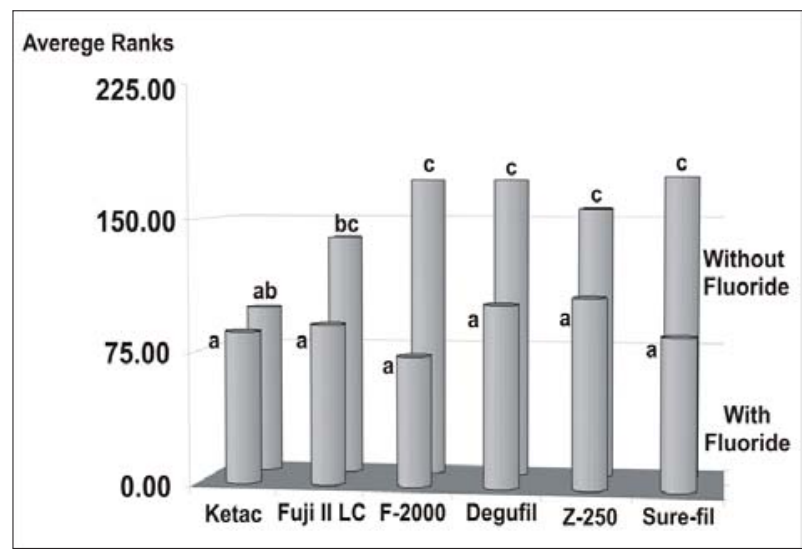

Figure 2. Comparison by visual examination scores of the cariostatic effect of the restorative materials associated with athe fluoridatated and non-fluoridatated dentifrices. 
Table 3. Results from the visual examination of the cariostatic potential of restorative materials associated with fluoridated and non-fluoridated dentifrices by scores.

Material Dentifrice $n \quad \begin{gathered}\text { Amplitude } \\ \\ \text { Median Low High }\end{gathered}$

$\begin{array}{lcccccc}\text { F2000 } & \text { F } & 20 & 1 & 0 & 2 & 73.25 \mathrm{a} \\ \text { Sure-fil } & \text { F } & 20 & 1 & 0 & 3 & 85.40 \mathrm{a} \\ \text { Ketac Fil } & \text { F } & 20 & 1 & 0 & 3 & 85.95 \mathrm{a} \\ \text { Fuji II LC } & \text { F } & 20 & 1 & 0 & 3 & 90.55 \mathrm{a} \\ \text { Ketac Fil } & \text { NF } & 20 & 1 & 0 & 3 & 96.52 \mathrm{ab} \\ \text { Degufil Mineral } & \text { F } & 19 & 1 & 0 & 2 & 102.42 \mathrm{ab} \\ \text { Z 250 } & \text { F } & 20 & 1 & 0 & 3 & 106.75 \mathrm{ab} \\ \text { Fuji II LC } & \text { NF } & 20 & 1 & 0 & 3 & 138.20 \mathrm{bc} \\ \text { Z 250 } & \text { NF } & 20 & 1 & 1 & 3 & 155.10 \mathrm{c} \\ \text { Degufil Mineral } & \text { NF } & 20 & 2 & 0 & 3 & 171.57 \mathrm{c} \\ \text { F2000 } & \text { NF } & 20 & 2 & 0 & 3 & 171.57 \mathrm{c} \\ \text { Sure-fil } & \text { NF } & 20 & 2 & 0 & 3 & 173.70 \mathrm{c}\end{array}$

$\mathrm{F}=$ fluoridated. $\mathrm{NF}=$ non-fluoridated. *Average ranks followed by different letters indicate statistically significant differences $(\alpha=0.05)$. lsd $(20-20)=42.85$. lsd (19-20) $=43.41$. lsd: least significance differences. $n=$ number of specimens. investigation of new materials before their clinical use and allows the conduction of studies in lesser time and at lower costs (13). In addition, reproducible results have been shown between visual inspection and microradiography and polarized light microscopy (17) and microhardness (13).

In this study, a four-point ordinal scale, as described by Serra and Rodrigues Jr. (7), was used. This scale was based on scales used in previous studies $(15,18)$ to evaluate not only the presence or absence of caries lesions, but also to quantify their activity and severity, considering that the opacity of the lesion increases as the mineral content decreases.

Artificial caries lesions were

\section{DISCUSSION}

The effect of fluoride-releasing restorative materials and fluoridated dentifrices is extremely important to prevent secondary caries formation. Fluoridated dentifrices have been investigated since the 1950's and fluoride-containing restorative materials have been studied since the 1970's Their cariostatic effects are very well known. Nevertheless, combination of fluoride-containing restorative materials and dentifrices has not been fully examined.

In this study, five calibrated examiners evaluated, by visual examination, the presence and severity of caries lesions using an experimental model that simulated clinical conditions (13). Visual inspection has been used to quantify opacities, fluorosis and white spots resulting from enamel demineralization in in vitro $(7,13,14)$, clinical (15), epidemiological (16) and in situ studies (17). Although it is considered a subjective caries detection method, visual inspection has some advantages compared to other methodologies, such as identification of differences in the cariostatic potential of restorative materials under conditions close to what occurs when white spot lesions are clinically detected (13). It is a simple method to perform, which facilitates laboratory produced using a dynamic $\mathrm{pH}$ cycling model (12) modified by the application of dentifrice slurries. Featherstone's et al. (12) model shows a correlation with the onset and progression of caries lesions in vivo in circumstances of high caries risk (12). This method simulates the demineralization and remineralization phenomena occurring in oral environment and has often been recommended to investigate the effects of different substances in dental caries prevention $(11,12,19)$.

The results of this study revealed that, irrespective of the dentifrice, the conventional glass ionomer cement (Ketac-fil) had the highest cariostatic effect among the restorative materials evaluated, which is consistent with the findings of previous studies (7). However, Ketac-fil did not differ statistically from the resin-modified glass ionomer (Fuji II LC), which is in accordance with other studies that observed a similar cariostatic effect between conventional and resin-modified glass ionomer cements $(10,11,19)$.

The association of the non-fluoridated dentifrice with Fuji II LC showed higher cariostatic effect than the association of the non-fluoridated dentifrice with the polyacid-modified composite resin and the composite resins (Degufil Mineral, Sure Fil, Z-250). These combinations of restorative materials and non-fluoridated dentifrice were statistically similar. These results may 
be explained by the calcium carbonate contents of the non-fluoride dentifrice, which are responsible for the dentifrice's high $\mathrm{pH}$ (19) and can neutralize the acid challenge during immersion in the demineralization solution.

The use of a fluoridated dentifrice was expected to increase the cariostatic effect of the glass ionomer cements because of their fluoride uptake ability and capacity of acting as a fluoride reservoir with slow release of fluoride, which can inhibit caries formation $(5,20)$. However, this effect was not evaluated in this study.

Higher cariostatic effect was observed when the tested restorative materials (Fuji II LC, F-2000, Degufil Mineral, Sure Fil and Z-250) were associated with a fluoridated dentifrice than with a non-fluoridated dentifrice. This occurred due to the effect of the fluoridated dentifrice, which provided a cariostatic effect on these materials. Such an effect was statistically similar for the glass ionomer cement Ketac-fil even when combined with fluoridated dentifrice.

It has been suggested that the use of fluoride dentifrices could inhibit the development of caries lesions around composite resin, glass ionomer, polyacidmodified composite resin or amalgam restorations $(18,20)$ in the same way. Donly and Kerber (20) affirmed that a critical level of fluoride concentration is necessary to inhibit caries lesion formation. If this level is reached, the cariostatic effect of the restorative material is less important.

The materials evaluated in this study have specific clinical indications regarding caries risk. However, if associated with use of an external fluoride source, such as fluoride-containing dentifrices, their primary indications may be reviewed and physical, mechanical and esthetic properties may be considered (20). In this study, all restorative materials had statistically similar cariostatic effect when associated with a fluoridated dentifrice, which suggests that, as long as a fluoridecontaining dentifrice is used, any of the tested materials could be indicated. The choice for composite resins seems to be the most attractive because of their better mechanical, physical and esthetic properties.

However, this was an in vitro study. Other factors should be considered under clinical conditions. The cariogenicity and frequency of the patient's diet, presence of saliva and bacteria producing acid challenges are important variables. Therefore, the dentist's decision to indicate a restorative material should be based on his/ her scientific background knowledge and take into account the patient's needs and caries risk (20).

The effectivenes of fluoride dentifrices, in spite of their ease of use and low cost, depends on patient training and compliance with oral hygiene procedures. If the patient's ability to remove dental plaque and his/ her frequency of use of fluoride dentifrices are questionable, glass ionomer cement should be the material of choice, especially for high-caries risk patients.

In conclusion, when the restorative materials were associated with a non-fluoridated dentifrice, the conventional glass ionomer cement showed the highest cariostatic potential. When the materials were associated with a fluoridated dentifrice there were no differences in their cariostatic potential. The conventional glass ionomer showed the same cariostatic effect with either the non-fluoridated or the fluoridated dentifrice.

\section{RESUMO}

O objetivo deste trabalho foi avaliar, in vitro, o efeito cariostático de 6 materiais restauradores contendo ou não flúor (Fuji II LC, F2000, Degufil Mineral, Sure Fil and Z-250) associados à aplicação de dentifrícios (fluoretado e não-fluoretado; Sensodyne Fórmula Original and Sensodyne Sodium Bicarbonate) em esmalte dental humano. Cavidades classe V foram preparadas no esmalte de 240 fragmentos dentais, aleatoriamente divididos em 12 grupos (6 materiais e 2 dentifrícios). Após serem restauradas as cavidades, os fragmentos foram submetidos a ciclos térmicos e de desmineralização e remineralização, simulando um alto desafio cariogênico. Sobre os fragmentos restaurados, ainda, foram aplicados dentifrícios contendo ou não flúor, 5 min por dia. As diferenças no desenvolvimento de lesões experimentais de cárie adjacente às restaurações foram avaliadas por 5 examinadores calibrados, através de inspeção visual, atribuindo-se escores de 0 a 3. Os resultados foram avaliados pelo teste de Kruskal-Wallis seguido pelo teste de comparações múltiplas $(\alpha=0,05)$. Quando associados ao dentifrício fluoretado, os materiais restauradores não diferiram entre si em relação ao potencial cariostático ( $>>0,05)$. Quando os materiais foram utilizados em associação com o dentifrício não-fluoretado o Ketac-Fil apresentou o maior potencial cariostático, seguido pelo Fuji II LC e pelos demais materiais. O Ketac-Fil foi o único material que não diferiu significativamente quando associado com o dentifrício com ou sem flúor. Sob as condições experimentais do estudo, a associação dos materiais restauradores ao dentifrício fluoretado resultou em uma maior ação cariostática, exceto para o cimento de ionômero de vidro convencional, que não diferiu com a aplicação dos dentifrícios.

\section{ACKNOWLEDGEMENTS}

We thank the financial support to CAPES and FAPESP, Professor 
Jaime A. Cury for fluoride analysis, and DFL for donation of some materials.

\section{REFERENCES}

1. Tantbirojn D, Douglas, WH, Versluis, A. Inhibitive effect of a resin-modified glass ionomer cement on remote enamel artificial caries. Caries Res 1997;31:275-280.

2. Dionysopoulos P, Kotsanos N, Papadogiannis Y, Konstantinidis A. Artificial secondary caries around two new F-containing restoratives. Oper Dent 1998;23:81-86.

3. White DJ. Reactivity of fluoride dentifrices with artificial caries. II. Effects on subsurface lesions: F uptake, F distribution, surface hardening and remineralization. Caries Res 1988;22:27-36.

4. Eichmiller FC, Marjenhoff WA. Fluoride-releasing dental restorative materials. Oper Dent 1998;23:218-228.

5. Hatibovic-Kofman S, Koch G. Fluoride release from glass ionomer cement in vitro and in vivo. Swed Dent J 1991;15:253-258.

6. Hattab FN, Mok NYC, Agnew EC. Artificially formed caries like lesions around restorative materials. J Am Dent Assoc 1989;118:193-197.

7. Serra MC, Rodrigues Jr AL. Potencial cariostático de materiais restauradores contendo flúor. Rev Assoc Paul Cir Dent 1998;52:359-363.

8. Zimmerman BF, Rawls HR, Querens AE. Prevention of in vitro secondary caries with an experimental fluorideexchanging restorative resin. J Dent Res 1984;63:689-692.

9. Smales RJ, Gao W. In vitro caries inhibition at the enamel margins of glass ionomer restoratives developed for the ART approach. J Dent 2000;28:249-256.

10. Dunne SM, Goolnik JS, Millar BJ, Seddon RP. Caries inhibition by a resin-modified and a conventional glass ionomer cement, in vitro. J Dent 1996;24:91-94.
11. Tam LE, Chan GPL, Yim D In vitro caries inhibition effects by conventional and resin-modified glass-ionomer restorations. Oper Dent 1997;22:4-14.

12. Featherstone JDB, O’Really MM, Shariati M, Brugler S. Enhancement of remineralization in vitro and in vivo. In Factors Relating to Demineralization and Remineralization of the Teeth. Leach SA (Editor). Oxford: IRL, 1986. p. 2334.

13. Serra MC. Análises sensorial e quantitativa do potencial cariostático de materiais restauradores contendo flúor. [Thesis (Livre Docência)]. Piracicaba: Faculdade de Odontologia de Piracicaba, Universidade Estadual de Campinas; 1999. $51 \mathrm{p}$

14. Edgar WM, Rugg-Gunn AJ, Jenkins GN, Geddes DA. Photographic and direct visual recording of experimental caries-like changes in human dental enamel. Arch Oral Biol 1978;23:667-673.

15. Gorelick L, Geiger AM, Gwinnet AJ. Incidence of white spot formation after bonding and banding. Am J Orthod 1982;81:93-98.

16. Backer-Dirks O. Posteruptive changes in dental enamel. J Dent Res 1966;45:503-511.

17. von der Fehr FR. The effect of fluorides on the caries resistance of enamel. Acta Odontol Scand 1961;19:431-442.

18. Twetman S, McWilliam JS, Hallgren A, Oliveby A. Cariostatic effect of glass ionomer retained orthodontic appliances. Swed Dent J 1997;21:169-175.

19. Glass RL, Shiere FR. A clinical trial of a calcium carbonate base dentifrice containing $0.76 \%$ sodium monofluorphosphate. Caries Res 1978;12:284-289.

20. Donly KJ, Kerber L. Demineralization inhibition at glassionomer cement and amalgam restoration margins in conjunction with additional fluoride regimens. Spec Care Dent 1999;19:24-28.

Accepted August 3, 2003 